\title{
KIAI DAN PENGEMBANGAN NILAI-NILAI MULTICULTURAL DI PONDOK PESANTREN AMANATUL UMMAH, PACET MOJOKERTO
}

\author{
Saifuddin*, Yaqub Cikusin** \\ *Universitas Islam Majapahit \\ Email : saifuddin167@gmail.com \\ **Universitas Islam Malang \\ Email : yaqub.cikusin@unisma.ac.id
}

\begin{abstract}
Abstrak
Multikulturalisme sesungguhnya sangat dekat dengan Islam. Nilai-nilai multicultural berjalan beriringan dengan nilai-nilai ajaran Islam. Implementasi dan praktik multikulturalisme di dunia pendidikan Islam telah berjalan dalam kehidupan alamiah masyarakat pesantren. Namun, multikulturalisme di pesantren tidak dapat dipisahkan dari peran serta seorang kiai sebagai pimpinan tertinggi. Tulisan ini mengungkap nilai multikultural yang terdapat dalam kehidupan alamiah masyarakat pesantren; ketika santri belajar, di asrama, mengaji, ketika santri makan, shalat, membaca wirid dan sebagainya. Selain itu, tulisan ini mengungkap keberadaan sosok kiai yang menjadi aktor dibalik berkembangnya nilai multikultural. Nilai-nilai multicultural diungkap dengan menelisik kehidupan sehari-hari santri, yang dalam pembumian nilai-nilai multicultural berjalan dengan alami. Dibalik itu semua, terdapat pola atau model yang dikembangkan oleh kiai yaitu; membentuk komunitas multicultural menghindari konflik sectarian menumbuhkan Islam moderat dan menangkal ideologi radikal.
\end{abstract}

Kata Kunci: Kiai, Pondok Pesantren, Nilai-nilai Multikultural

\section{Abstract}

Multiculturalism is highly relevant to Islam. Multicultural values go alongside Islamic values. The implementation and practice of multiculturalism in Islamic education has been running in the natural life of the pesantren community. However, multiculturalism in pesantren cannot be separated from the participation of a kiai as the highest leader. This paper reveals the multicultural values found in the natural life of the pesantren community; when the students study, in the dormitory, the Koran, when they eat, pray, read wirid and so on. In addition, this paper reveals the existence of a kiai figure who is the actor behind the development of multicultural values. Multicultural values are revealed by examining the daily life of students, which in the grounding of multicultural values runs naturally. Behind all that, there are patterns or models developed by the 
kiai, namely; building multicultural communities - avoiding sectarian conflicts - fostering moderate Islam and countering radical ideologies.

Keywords: Kiai, Islamic Boarding School, Multicultural Values PENDAHULUAN

Pondok pesantren adalah lembaga pendidikan yang tak terpisahkan dari sejarah bangsa Indonesia. Pondok pesantren telah memberikan kontribusi signifikan bagi kemajuan dan pembangunan bangsa, baik sejak era kolonial hingga pasca-kemerdekaan. Pada mulanya Pondok pesantren merupakan sebuah lembaga pendidikan Islam tradisional yang menitikberatkan pada pendidikan agama, namun pada perkembangan berikutnya pendidikan pondok pesantren telah bermetamorfosa menjadi lembaga pendidikan modern dengan segala dinamika yang mengiringinya.

Pondok Pesantren Amanatul Ummah yang menjadi lokasi penelitian ini berada di Desa Kembang Belor, Mojokerto, tepatnya di kawasan Pacet. Keberadaan pesantren ini di area pedesaan yang jauh dari hingar bingar dan kebisingan kota justru menjadikan lembaga pendidikan ini cukup produktif dalam menghasilkan santri berkualitas dengan torehan prestasi yang mengagumkan. Produktifitas tinggi tersebut tidak lepas dari tangan dingin sang pengasuh, yaitu KH. Asep Saifuddin Chalim.

Sebagai pendiri dan pengelola lembaga pendidikan pesantren, kiai menawarkan desain pendidikan pesantren yang dapat menumbuhkan nilainilai multikultural. Kiai Asep mempunyai harapan dan cita-cita besar terkait Islam dan dunia pendidikan. Islam di Indonesia-menurut Kiai-“"sangat layak untuk dipromosikan dan disajikan di dunia internasional. Untuk itu sang Kyai perlu untuk mendatangkan santri (mahasiswa) dari berbagai latar belakang Negara untuk menimba Ilmu di pondok pesantren amanatul ummah.Para santri yang belajar di pesantren ini terdiri dari latar belakang yang berbeda. Misalnya

Abdul Waleed dan Saddam Husein, keduanya berasal dari Afghanistan, sebuah negeri berpenduduk mayoritas muslim yang mengalami pertikaian antar warganya akibat perselisihan politik yang tidak kunjung usai. Namun pada kenyataannya, mereka harus berkomunikasi dengan mayoritas santri asal Indonesia dan sebagian dari Negara lain yang tidak lancar penggunaan bahasa percakapan internasionalnya. Lambat laun, kendala perbedaan bahasa sedikit demi sedikit teratasi, karena santri Amanatul Ummah sangat ditekankan untuk menggunakan bahasa Internasional dalam percakapan sehari-hari.

Berangkat dari sini, sang Kyai coba mengembangkan pendidikan dengan nilai-nilai moderasi dan prinsip Islam rahmatan lil 'alamin yang mana, nilai-nilai tersebut semakin hilang dari wajah Islam dunia. Dengan tujuan selain membesarkan lembaga, pendidikan ini akan semakin 
mempertegas nilai tawar Indonesia sebagai Negara Islam yang moderat. Sehingga pengembangan nilai-nilai multicultural di Amanatu Ummah sangat dikembangkan oleh kyai Asep dan menarik untuk dibahas berikut ini

\section{METODE PENELITIAN}

Jenis yang dipilih dalam penelitian ini adalah kualitatif dengan pendekatan fenomenologi. Seperti yang diungkapkan oleh Creswell, penelitian kualitatif berusaha mengkaji fenomena sosial dan masalah manusia. ${ }^{1}$ Penelitian ini hendak memahami gejala yang terjadi pada obyek penelitian dengan cara mendeskripsikan fenomena multikultural yang terdapat dalam pendidikan pesantren, dengan sosok Kiai sebagai aktor utama atas terbentuknya fenomena multikultural di pesantren.

Sedangkan data penelitian diperoleh melalui subyek dan informan penelitian yang terdiri dari unsur kiai, pengurus pondok, guru/ustadz, pengurus asrama dan santri selain pengamatan pada peristiwa atau aktifitas.. Adapun teknik pengumpulan data, sebagaimana lazimnya penelitian kualitatif, menggunakan wawancara mendalam, observasi partisipan, dan dokumentasi. Setelah data terkumpul, selanjutnya adata dianalisa menggunakan model Miles dan Huberman yang terdiri dari tiga alur, yaitu: reduksi data, penyajian data, dan kondensasi. Dan terakhir untuk mengecek keakuratan dan keabasahan data digunakan teknik triangulasi.

\section{PEMBAHASAN}

Dalam tulisan ini, sosok kiai dalam pesantren, akan digambarkan sebagai aktor dalam mengembangkan nilai dan kehidupan multikultural di pesantren karena fungsi dan perannya yang sentral dan strategis. Oleh karenanya, Kiai akan dilihat dari "angle" sebagai seorang "pembawa perubahan" dengan beberapa tawaran agenda perubahan, yang diperkuat dengan "rasionalitas tokoh agama", di mana kiai sebagai pemimpin dalam agama dan masyarakat sudah cenderung rasional dan terbuka dalam membaca fenomena yang terjadi. Konsep tentang kiai sebagai "pembawa perubahan" sesungguhnya telah diperkenalkan oleh Horikoshi (1987). Dalam penelitiannya tentang sosok kiai di pedalaman Jawa Barat, Horikoshi menekankan tentang peran kreatif kiai dalam perubahan social. Sosok kiai bukanlah bertindak sebagai peredam dinamika perubahan yang terjadi, namun dengan caranya sendiri kiai memberikan tawaran agenda perubahan yang dianggapnya sesuai dengan kebutuhan masyarakatnya. Hasil penelitian Horikoshi tentang kiai dan perubahan sosial adalah kelanjutan sekaligus

1 John W. Creswell. 2014. "Research Design: Pendekatan Kualitatif, Kuantitatif dan Mixed”. Yogyakarta: Pustaka Pelajar. 
kritik terhadap tesis Geertz bahwa kiai adalah seorang pialang budaya (cultural broker), sehingga teori Horikoshi erat kaitannya dengan teori Geertz.

Ide Schraf tentang "rasionalitas tokoh agama" (Scharf, 1995: 54) juga relevan dengan tema ini. Rasionalitas tokoh agama adalah cara-cara interpretasi doktrin agama secara praktis dan sistematis untuk mengatasi persoalan yang terjadi dalam masyarakat. Teori ini merupakan arah untuk mengkaji munculnya rasionalitas kepemimpinan K.H. Asep Saifuddin Chalim, pemimpin sekaligus pengasuh pesantren Amanatul Ummah. Pertimbangan rasionalitasnya, ketika menguatnya eksklusivisme dalam beragama, maka nilai-nilai keagamaan yang lebih toleran harus dikedepankan. Perilaku rasionalitas tokoh agama, terutama dalam hal kepemimpinan kiai terlihat dari dua hal Pertama, interpretasi spiritual di mana kyai melakukan interpretasi sistem pendidikan pesantren dengan cara memadukannya dengan sistem pendidikan umum sehingga menjadi sistem pendidikan pesantren terpadu. Kedua interpretasi tujuan, materi, metode, dan kegiatan keagamaan yang masih global, umum dan abstrak ke arah spesifik, jelas dan sistematis untuk menyesuaikan sistem pendidikan di sekolah dan kebutuhan santri serta dinamika masyarakat. ${ }^{2}$

Kemampuan Kiai dalam merancang dan merekayasa kehidupan sosial di pondok pesantren tidak lepas dari bentuk karakter pesantren yang dinamis. Sehingga penelitian ini juga mengambil teori dinamisasi pesantren yang digaungkan oleh Abdurrahman Wahid. Dinamisasi yang terjadi dalam pendidikan pesantren, pada dasarnya mencakup dua buah proses, yaitu penggalakan kembali nilai-nilai hidup positif yang telah ada. Selain itu juga proses dinamisasi juga meliputi penggantian nilai-nilai lama dengan nilainilai baru yang dianggap lebih sempurna dan lebih mampu diterapkan. Proses penggantian nilai, atau lebih tepatnya adalah proses penyerapan pesantren terhadap nilai-nilai baru dinamai dengan modernisasi. Dari keterangan ini maka jelaslah bahwa pengertian modernisasi pondok pesantren juga tercakup dalam pengertian dinamisasi. Demikian Wahid menjelaskan kemampuan pesantren membaca gerak zaman. ${ }^{3}$

Dalam tulisan ini akan dipaparkan tentang nilai-nilai multicultural dalam kehidupan masyarakat pesantren (PP. Amanatul Ummah) serta model pengembangan nilai muhltikultural oleh kiai.

2 Dakir, 2004. "Pola Baru Kepemimpinan Kiai dalam Pengembangan Pendidikan”. STAIN Palangka Raya: Jurnal Studi Agama dan Masyarakat

${ }^{3}$ Abdurrahman Wahid. 1978. Bunga Rampai Pesantren. Jakarta: Dharma Bakti. 


\section{Nilai-nilai Multicultural dalam Kehidupan Pesantren}

Sehubungan dengan nilai-nilai multikultural di pondok pesantren Amanatul Ummah, ditemukan beberapa nilai yang ada dalam keseharian para santri yaitu;

a. Nilai Kebersamaan

b. Nilai Toleransi dalam Keragaman

c. Nilai Kerjasama

d. Nilai Kasih Sayang

e. Nilai Musyawarah

f. Nilai Keadilan

g. Nilai Demokrasi

h. Nilai Menghilangkan Kecurigaan (prejudice reduction)

Nilai KesetaraanNilai-nilai multikultural yang ada adalah hasil dari interaksi para santri di pondok pesantren berdasarkan kehidupan alami di dalamnya. Sebagaimana penjelasan Gus Dur, bahwa pondok pesantren adalah sub-kultur dari masyarakat. Nilai-nilai multikultural yang ada diungkap melalui teknik observasi dan wawancara, adapun temuan penelitian dari fokus pertama ini adalah:

Pertama, nilai kebersamaan. Nilai kebersamaan. Nilai kebersamaan yang terjalin di antara para santri terlihat dari cara santri mengorganisir pola makan sehari-hari, baik makan pagi, siang maupun makan malam. Cara makan santri menggunakan nampan berukuran besar yang dapat menampung tujuh hingga Sembilan santri untuk satu porsi makan. Santri Amanatul Ummah yang terdiri dari aneka ragam latar belakang, baik budaya maupun stratifikasi social dapat disatukan dalam satu periuk makan. Begitu pula ketika saat istirahat tiba. Latar belakang ekonomi dan social santri tidak menjadikan mereka berbeda. Para santri hidup menyatu dengan alas tidur atau karpet yang dapat menampung tiga hingga empat santri dalam satu alas tidur. Nilai kebersamaan muncul dari kehidupan sehari-hari di pondok pesantren.

Kedua, nilai toleransi dalam keragaman. Toleransi dalam keragaman dapat peneliti temukan pada pertunjukan teater yang dilakukan oleh para santri disekolah. Kegiatan ini di sekolah Madrasah Aliyah Bertaraf Internasional (MBI) dilaksanakan oleh para santri dalam acara Pekan Karya Santri Madrasah Bertaraf Internasional atau PAKARSAMBI. Dalam kegiatan itu santri mengangkat tema "toleransi beragama". Tema toleransi beragama dipilih karena kepriharinan santri melihat maraknya fenomena diskriminasi yang ditujukan kepada penganut agama lain, terutama agama minoritas. Melalui tema ini sesungguhnya ada nilai multikultural yang hendak disuarakan oleh para santri. Nilai multikultural ini lahir dari 
kesadaran santri akibat dari moderasi pemahaman agama yang ada di lingkungan pesantren.

Ketiga, nilai kerja sama. Bentuk kerja sama dalam kehidupan santri dapat ditemukan pada saat santri mendesain ruang belajar di kelas masingmasing agar suasana belajar tampak kompetitif. Hal ini tidak lepas dari kebijakan bahwa ada sistem kompetisi yang dibangun di lingkungan pondok pesantren melibatkan kelas-kelas belajar. Penentuan kelas terbaik dapat dilihat dari kerapian kelas hingga penggunaan bahasa asing oleh para anggota kelas. Kelas terbaik mendapat gelar atau predikat amazing class. Sehingga dengan model kompetisi ini para siswa dalam kelas akan saling berlomba dan bekerja sama untuk menjadikan kelas masing-masing menjadi amazing class. Selain di kelas kerja sama di antara para santri juga terdapat di asrama. Asrama yang dinilai sebagai asrama terbaik akan mendapatkan gelar ahsanul ghurfah. Gelar itu dalam bahasa Indonesia berarti kamar terbaik. Nilai kerja sama yang tumbuh di antara para santri merupakan desain dari pengurus pondok yang tercipta dari sistem kompetisi antar kelas.

Keempat, nilai kasih sayang. Nilai kasih sayang dapat dilihat dari perhatian lembaga terhadap para santrinya. Baik perhatian selama santri belajar maupaun perhatian pada saat santri sudah lulus, karena pondok pesantren Amanatul Ummah dibawah asuhan Kiai Asep sangat memperhatikan keberlangsungan pendidikan santri bahkan hingga santri lulus dari pesantren. Peneliti menemukan bentuk kasih sayang kepada para santri setelah lulus dari pesantren ketika Amanatul Ummah memfasilitasi para santri lulusan Amanatul Ummah untuk melanjutkan studi lanjut di berbagai perguruan tinggi terbaik baik di tingkat nasional maupun di luar negeri. Bahkan Kiai Asep membentuk tim khusus untuk mendampingi santri mengikuti seleksi masuk perguruan tinggi. Bentuk perhatian ini adalah bentuk kasih sayang. Nilai kasih sayang yang berhubungan erat dengan orientasi pendidikan yang dianut oleh kiai.

Kelima, nilai musyawarah. Nilai musyawarah dapat ditemukan dalam wujud kegiatan yang dibentuk oleh pengurus pondok pesantren dalam rangka meningkatkan kreatifitas mengembangkan kemampuan berbahasa asing santri. Ada lembaga yang diorganisir sendiri oleh para santri yaitu LAPENSA atau Lembaga Pendidikan Bahasa. Para santri anggota LAPENSA senantiasa berinovasi merumuskan agenda atau bentuk terbaik dalam peningkatan kualitas berbahasa santri, terutama bahasa asing Arab dan Inggris. Diantara para santri selalu terlibat musyawarah dalam menjalankan LAPENSA. Selain itu terdapat juga BKS (Brigadir Kedisiplinan Santri). BKS dibentuk untuk memantau kedisiplinan santri, tentu anggota adalah para santri sendiri, melalui LAPENSA dan BKS nilai 
musyawarah dalam internal santri selalu ada. Nilai yang sesungguhnya didesain sejalan dengan desain menjalankan aktifitas pendidikan.

Keenam, nilai keadilan. Nilai keadilan dalam kehidupan santri juga terlihat dari anggota kamar. Di pondok pesantren ini tidak ditemukan adanya diskriminasi dalam penempatan kamar tidur santri. Semua santri membaur ditempatkan pada kamar-kamar yang telah tersedia tanpa harus melihat asal daerah santri atau perbedaan santri berdasarkan status sosial. Tetapi yang menjadi pengecualian adalah penanganan terhadap santri yang berasal dari luar negeri. Di PP Amanatul Ummah santri luar negeri, ditempatkan pada satu asrama khusus, yang berbeda dengan santri dari dalam negeri. Namun perlu ditekankan, bahwa perbedaan penempatan asrama santri dalam dan luar negeri adalah karena alasan untuk mempermudah koordinasi dan pengawasan serta menghindari hal-hal negatif karena banyak di antara para santri luar negeri yang belum fasih berbahasa Indonesia.

Ketujuh, nilai demokrasi. Amanatul Ummah senantiasa berupaya untuk memenuhi kebutuhan masyarakat akan pendidikan pesantren. Pendidikan yang ditawarkan Amanatul Ummah adalah dalam rangka menjawab tantangan zaman namun tetap tidak kehilangan jatidiri sebagai pondok pesantren. Beberapa tawaran tentang pilihan pendidikan sesungguhnya dapat disimpulkan menjadi pendidikan agama khas "pesantren salaf" dan "pendidikan umum" yang membekali santri untuk melanjutkan ke perguruan tinggi dengan disiplin ilmu umum. Kebebasan santri untuk memilih model pendidikan yang diminatinya adalah temuan dari nilai demokrasi yang ada di pondok pesantren Amanatul Ummah. Nilai demokrasi yang muncul di tengah upaya mengembangkan pendidikan pesantren.

Kedelapan, nilai menghilangkan kecurigaan (prejudice reduction). Menghilangkan kecurigaan sebagai bagian penting dari upaya membangun masyarakat multikultural dapat terlihat dari cara kiai asep mengatur lembaga pendidikan dan mengatur para santri. Kiai tidak menghendaki adanya monokultural dalam pesantrennya dalam arti pendidikan hanya diperuntukkan bagi santri dari latar belakang organisasi keagamaan tertentu. Bagi Kiai Asep pendidikan dapat dinikmati oleh seluruh elemen masyarakat tanpa melihat latar belakang organisasi keagamaannya. Sehingga kiai melarang adanya penggunaan simbol-simbol organisasi keagamaan tertentu yang tujuannya adalah untuk menghilangkan kecurigaan diantara para santri.

Kesembilan, nilai kesetaraan. Nilai kesetaraan yang bisa ditemukan dari cara santri shalat berjamaah yang kesemuanya menggunakan seragam baju dan kopyah putih. Kesetaraan diantara para santri juga terlihat dari 
penempatan santri di kamar-kamar atau asrama. Penempatan kamar yang mempertimbangkan prinsip-prinsip kesetaraan dengan tidak melihat latar belakang social, budaya, maupun status social. Santri yang diterima di Amanatul Ummah adalah ibarat satu keluarga utuh. Meskipun santri dari luar negeri mendapat kamar yang berbeda dari para santri dari dalam negeri, namun pembedaan kamar itu adalah dalam rangka menanggulangi keterkejutan budaya (cultural shock) santri luar negeri dan juga agar program penguasaan bahasa Indonesia lebih optimal. Pembedaan kamar bukan bagian dari praktik diskriminasi.

\section{Model Pengembangan Nilai-nilai Multikultural}

Model adalah gambaran yang sangat jelas dan dan rinci tentang sebuah kegiatan yang seharusnya memiliki prosedur sistematis. Model merupakan pola atau kerangka yang hendak dijadikan contoh atau rujukan. Temuan penelitian tentang model pengembangan nilai-nilai multikultural di Pondok Pesantren Amanatul Ummah mengindikasikan bahwa kiai mempunyai peran dan posisi strategis. Melalui kebijakan dan strategi mengembangkan pendidikan pesantren kiai telah dengan tegas menciptakan dan membuka ruang-ruang multikultural pada masyarakat pesantren. Di sisi lain juga kiai mempersempit ruang-ruang anti-multikultural. Adapun untuk lebih jelasnya temuan penelitian dari fokus ketiga ini adalah:

a) Membentuk komunitas multikultural

Sebagai konseptor pendidikan pesantren, kiai merasa terusik dengan kenyataan bahwa pendidikan pesantren adalah pendidikan tradisional yang tertinggal. Kiai merasa pendidikan Islam yang menjadi ciri khas pesantren sudah selayaknya dikembangkan dan dipromosikan bahkan hingga ke manca Negara. Islam Indonesia adalah Islam yang moderat sehingga cocok dengan perkembangan konstelasi politik global, terutama yang berhubungan dengan Negara-negara Islam. Fakta menunjukkan Negara-negara Islam di belahan bumi yang lain dilanda konflik yang tidak kunjung mereda. Menurut Kiai Asep Islam Indonesia akan mampu menjadi jawaban dari didnamika problem umat Islam kontemporer.

Atas keresahan kondisi umat Islam serta keinginan kuat untuk memajukan pendidikan pesantren, Kiai Asep gencar melakukan promosi pendidikannya ke luar negeri. Dalam waktu yang relatif singkat, Pondok Pesantren Amanatul Ummah menjelma menjadi pesantren internasional dengan komposisi santri dari berbagai Negara. Kehadiran santri dari berbagai Negara adalah ide dan gagasan kiai untuk mengembangkan pendidikan pesantren yang sekaligus gagasan tersebut dengan sendirinya membentuk komunitas multikultural. Hal ini dikarenakan berkumpulnya aneka perbedaan latar belakang dari setiap anggota masyarakat (dalam hal ini adalah masyarakat pesantren) adalah merupakan bentuk dari komunitas 
multikultural. Komunitas multikultural yang terbentuk adalah karena mengembangkan lembaga pendidikan pondok pesantren.

b) Menghindari bangkitnya isu sektarianisme

Nilai-nilai multikultural dapat berkembang di Pondok Pesantren Amanatul Ummah sebagaimana pemaparan di atas adalah komitmen kiai tentang lembaga pendidikan yang dipimpinnya menjadi lembaga pendidikan besar dan sangat diminati masyarakat. Bagi Kiai Asep, pendidikan pondok pesantren adalah aset umat Islam di Indonesia. Sehingga konsekwensinya, pendidikan berkualitas yang dikembangkan Pondok Pesantren Amanatul Ummah harus bisa dirasakan keberadaannya dan memberikan manfaat seluas-luasnya kepada umat Islam Indonesia. Kiai Asep tidak berkenan apabila pondok pesantren yang dipimpinnya hanya bisa diakses oleh satu entitas kelompok masyarakat saja. Misalnya organisasi kemasyarakatan berbasis agama Nahdlatul Ulama (NU). Kendatipun Kiai Asep adalah kiai yang juga mempunyai jabatan struktural di NU, namun kiai tidak menghendaki pendidikan pondok pesantrennya hanya untuk warga nahdliyyin. Kiai tetap berkomitmen lembaga pendidikannya untuk semua kalangan umat Islam.

Konsistensi Kiai Asep dalam menjaga orientasi pendidikan pondok pesantrennya, terlihat dari arahan serta aturan yang disampaikan kepada para santrinya. Baik dengan teguran secara lisan maupun wejangan ketika ngaji yang diikuti oleh para santri. Sebagaimana paparan data penelitian, kiai melarang santrinya yang berasal dari warga nahdliyyin untuk menampakkan symbol-simbol khas Nahdlatul Ulama' baik bendera atau logo yang disejajarkan dengan logo pondok pesantren. Hal ini demi menjaga kemungkinan-kemungkinan buruk yang tidak diinginkan yang terjadi mengingat begitu beragamnya latarbelakang orientasi keagamaan santri. Komitmen yang dipegang oleh kiai selaras dengan nilai-nilai multikultural dimana satu fihak tidak dapat memaksakan kehendak pada orang lain untuk mengikuti apa yang diyakini. Di sisi lain tetap juga menghargai pihak lain yang mempunyai orientasi dan pandangan yang berbeda-beda. Memaksakan orientasi keagamaan kepada pihak lain dapat mencederai multikulturalisme, atas dasar itu kiai melarang penggunaan atribut dan symbol organisasi keagamaan sebagai bagian dari mencegas bangkitnya isu sektarianisme yang dapat mengganggu kehidupan multikultural di pondok pesantren.

c) Menumbuhkan pemahaman Islam moderat di kalangan santri

Penjelasan ketiga adalah seputar Islam moderat serta radikalisme dalam dunia pendidikan yang sudah menjadi pembicaraan hangat dalam masyarakat. Tidak terkecuali tentang radikalisme di kalangan santri. Mudahnya semua orang mengakses informasi melalui jejaring social, membuat siapa saja dapat mengakses informasi tentang apa saja dan dari 
mana saja, termasuk mengakses informasi propaganda dari kalangan Islam yang berideologi Ekstrim. Dalam hal membentengi lembaga pendidikannya dari pengaruh dan ancaman ideologi ekstrim ini, Kiai Asep tanpa ragu berupaya membentengi santri dan pondok pesantrennya dari pengaruh Hizbut Tahrir Indonesia (HTI) karena ideologinya membahayakan bagi kelangsungan bernegara. Sebagaimana paparan data penelitian, Kiai Asep adalah kiai dengan jiwa nasionalisme tinggi, sebagaimana kiai NU pada umumnya yang telah memadukan antara gagasan bernegara dan konsep beragama.

Penjelasan di atas menunjukkan kiai Asep sangat tegas melarang para santrinya untuk mengikuti gerakan khilafahisme yang diusung oleh HTI. Ideologi khilafahisme ditolak oleh kiai karena tidak sejalan dengan cita-cita membangun masyarakat multikultural. Kiai juga menyadari bahwa lembaga pendidikan adalah lahan subur tumbuhnya radikalisme dalam agama, sebagaimana yang terjadi di lembaga-lembaga pendidikan tinggi di Indonesia. Atas dasar itu meminimalisir benih radikalisme agama di kalangan santri Amanatul Ummah adalah upaya serius dari kiai untuk mengembangkan nilai-nilai multikultural di pondok pesantren. Hal ini disebabkan radikalisme agama akan menumbuhkan nilai-nilai yang anti terhadap multikulturalisme.

\section{KESIMPULAN}

Nilai-nilai multicultural dapat berkembang dengan sendirinya secara natural di pondok pesantren. Hal ini mengindikasikan kehidupan keseharian di pondok pesantren, mempunyai hungungan yang sangat kuat dengan multikulturalisme. Adapun nilai-nilai multicultural yang ada di Pondok Pesantren Amanatul Ummah, yaitu: (i) Nilai Kebersamaan; (ii) Nilai Toleransi dalam Keragaman; (iii) Nilai Kerjasama; (iv) Nilai Kasih Sayang; (v) Nilai Musyawarah; (vi) Nilai Keadilan; (vii) Nilai Demokrasi; (viii) Nilai Menghilangkan Kecurigaan (prejudice reduction); dan (ix) Nilai Kesetaraan. Pondok pesantren adalah lahan yang subur bagi tersemainya benih-benih multikultural yang responsif-adaptif terhadap perkembangan dunia pendidikan serta dinamika konstelasi geopolitik baik nasional maupun dalam skala internasional. Pondok pesantren turut berperan aktif dalam menyebarkan gagasan tentang nilai-nilai multikultural, di saat gejala tentang eksklusivisme dan radikalisme agama dalam Islam sedang mengalami trend peningkatan. Sehingga berangkat dari teori besar ajaran Alquran tentang keniscayaan kemajemukan masyarakat, suku, warna kulit, bahasa, agama dan lain sebagainya dalam konstruksi multikulturalisme, penelitian ini mengungkap nilai-nilai multikultural yang ada di lembaga pendidikan pesantren. Nilai-nilai multikultural yang terdapat pada kehidupan sehari-hari 
para santri ketika santri belajar, di asrama, mengaji, ketika santri makan, shalat, membaca wirid dan sebagainya

Model pengembangan nilai-nilai multicultural kiai dalam masyarakat pesantren dicapai melalui tiga hal; pertama, membentuk komunitas multikultural; yaitu keadaan dimana santri Amanatul Ummah berasal dari berbagai latar belakang sosial dan budaya, serta kebijakan kiai yang mendatangkan santri dari luar negeri menjadikan Pondok Pesantren ini rumah bagi keragaman. Kedua, menghindari bangkitnya isu sektarianisme; yaitu kiai menghindari perilaku eksklusif dengan bersikap menutup diri dari kelompok dan faham keagamaan yang berbeda dengan yang dianutnya. Kiai terbuka menerima santri di luar NU serta melarang eksklusifisme di lembaganya. Ketiga, menumbuhkan pemahaman Islam moderat di kalangan santri; yaitu penolakan kiai terhadap ideology radikal dalam bentuk organisasi yang hendak merubah dasar Negara untuk memasuki lembaga pesantren. Sebagaimana teori Horikoshi tentang kiai dan perubahan sosial, dalam konteks penelitian ini, kiai menjadi aktor utama dalam mengemas pondok pesantren menjadi lebih ramah, toleran dan terbuka dalam koridor multikulturalisme, dengan cara membuka ruangruang multicultural serta membatasi ruang gerak nilai-nilai antimultikultural. Kiai menjadi inisiator pengembangan nilai-nilai multicultural melalui terobosan-terobosan besar tentang agenda pendidikan. Penelitian ini menunjukkan bahwa mengembangkan pendidikan pesantren adalah sekaligus mengembangkan nilai-nilai multikultural.

\section{DAFTAR PUSTAKA}

Abdurrahman Wahid. 2001. Menggerakkan Tradisi: Esai-Esai Pesantren. Yogyakarta: LKiS.

Abdurrahman Wahid. 1978. Bunga Rampai Pesantren. Jakarta: Dharma Bakti.

Clifford Geertz. 1981. Abangan, Santri, Priyayi dalam Masyarakat Jawa (Terjemahan oleh Aswab Mahasin). Jakarta: Pustaka Jaya.

Dakir, 2004. "Pola Baru Kepemimpinan Kiai dalam Pengembangan Pendidikan". STAIN Palangka Raya: Jurnal Studi Agama dan Masyarakat

Hiroko Horikoshi, 1987. Kiai dan Perubahan Sosial. Terjemahan Umar Barsalim. Jakarta: P3M.

Jhon W. Cresswell, 2012. Eduactional Research: Planning, Conducting, and Evaluating Quantitative and Qualitative Research. Ney Jersey: Person Education Inc.

John W. Creswell. 2014. "Research Design: Pendekatan Kualitatif, Kuantitatif dan Mixed”. Yogyakarta: Pustaka Pelajar. 